\title{
25 Research Square \\ Bile acid synthesis disorders in Japan: long-term outcome and chenodeoxycholic acid treatment
}

\section{Akihiko Kimura}

Kurume University School of Medicine

Tatsuki Mizuochi ( $\nabla$ mizuochi_tatsuki@kurume-u.ac.jp )

Kurume University School of Medicine https://orcid.org/0000-0002-2943-7068

\section{Hajime Takei}

Junshin Clinic Bile Acid Institute

\section{Akira Ohtake}

Saitame Medical University

Jun Mori

Kyoto Prefectural University of Medicine

\section{Kunihiro Shinoda}

Gifu Municipal Hospital

\section{Takuji Hashimoto}

Toho University School of Medicine

\section{Mureo Kasahara}

National Center for Child Health and Development

\section{Takao Togawa}

Nagoya City University Graduate School of Medical Sciences

\section{Tsuyoshi Murai}

Health Sciences University of Hokkaido

\section{Takashi lida}

Nihon University

\section{Hiroshi Nittono}

Junshin Clinic Bile Acid Institute

\section{Research}

Keywords: bile acid synthesis disorders, bile acid analysis, chenodeoxycholic acid treatment, HSD3B7, SRD5B1, CYP7B1

Posted Date: January 28th, 2020

DOI: https://doi.org/10.21203/rs.2.22018/v1 
License: (c) (i) This work is licensed under a Creative Commons Attribution 4.0 International License. Read Full License

Version of Record: A version of this preprint was published at Digestive Diseases and Sciences on January 1st, 2021. See the published version at https://doi.org/10.1007/s10620-020-06722-4. 


\section{Abstract}

Background: We encountered 7 Japanese patients with bile acid synthesis disorders (BASD) over 21 years between 1996 and 2017. Diagnoses were made by bile acid and genetic analyses. We gave lowdose, long-term chenodeoxycholic acid (CDCA) treatment to 5 of the patients, who had $3 \beta$-hydroxy- $\triangle 5-C$

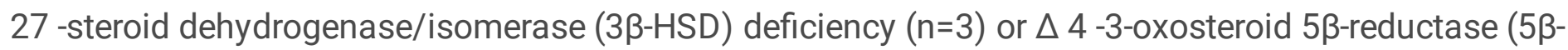
reductase) deficiency $(n=2)$. Another patient with the latter diagnosis whose bile acid analyses had mitigating features was maintained on ursodeoxycholic acid according to parental preferences and now remains healthy after discontinuation of treatment. A patient with oxysterol 7a-hydroxylase deficiency developed liver failure and fully recovered after successful liver transplantation. We used clinical records to clarify long-term outcome and value of CDCA in the other patients. Efficacy of CDCA treatment was evaluated in the 5 patients given a low dose ( 5 to $10 \mathrm{mg} / \mathrm{kg} / \mathrm{day}$ ) for a long term.

Results: Medians with ranges of current patient ages and duration of CDCA treatment are10 years (8 to 43) and 10 years (8 to 21), respectively. All 7 patients, who had homozygous or compound heterozygous mutations in the HSD3B7, SRD5B1, or CYP7B1 gene, are currently in good health without liver dysfunction. In the 5 patients with CDCA treatment, hepatic function gradually improved following initiation. No adverse effects were noted.

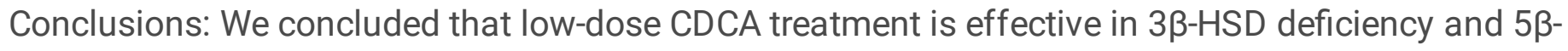
reductase deficiency, as cholic acid has been in other countries. BASD carry a good prognosis following early diagnosis and initiation of long-term, low-dose CDCA treatment.

\section{Introduction}

Since 1987, 6 bile acid synthesis disorders (BASD) caused by single-enzyme defects, including $3 \beta-$

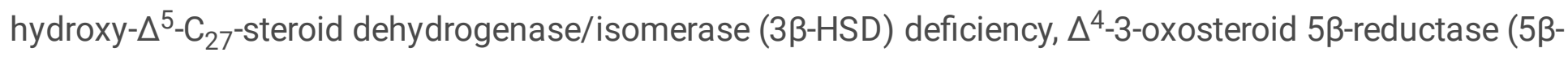
reductase) deficiency, oxysterol 7a-hydroxylase (oxysterol 7a) deficiency, sterol 27 hydroxylase deficiency, bile acid-CoA ligase deficiency, and bile acid-CoA: amino acid N-acyltransferase deficiency have been reported.[1-6] The first known Japanese BASD patient, who had 33-HSD deficiency, was reported in 1998. $[7,8]$ Subsequently Japanese 5 $\beta$-reductase deficiency and oxysterol 7a deficiency cases have been reported, but neither sterol 27 hydroxylase deficiency (except in adults or older children with cerebrotendinous xanthomatosis) nor amidation defects are known to have arisen in Japan.[9-11] No standard samples for unusual bile acids such as $3 \beta$-hydroxy- $\Delta^{5}, 3-0 x 0-\Delta^{4}$ and allo-bile acids were available, while a few pediatricians with an interest in neonatal cholestasis may have made a delayed diagnosis of BASD in Japan.

BASD are rare autosomal recessive inherited disorders. Considering all known cases worldwide, the most frequent defect is $3 \beta$-HSD deficiency (OMIM 607765), arising from mutations in HSD3B7. Next in frequency are 5 $\beta$-reductase deficiency (OMIM 235555), caused by mutations in SRD5B1 (AKR1D1) and oxysterol 7a deficiency (OMIM 603711) due to mutations in CYP7B1.[12] These 3 disorders often present 
in the first few months of life as cholestasis with conjugated hyperbilirubinemia and elevated transaminases, usually progressing to cirrhosis if untreated. Absence of pruritus and normal serum $\mathrm{Y}^{-}$ glutamyltransferase (GGT) and normal or low serum total bile acids (TBA) using 3a-hydroxysteroid dehydrogenase enzyme method concentrations have been emphasized as characteristic findings in BASD, such as $3 \beta$-HSD deficiency, $5 \beta$-reductase deficiency, and oxysterol 7a deficiency. $[1-3,12]$ On the other hand, when GGT and TBA are in the normal range, amidation defects cannot be diagnosed.[5, 6$]$

Following our diagnosis of 2 patients with $3 \beta$-HSD deficiency, we have analyzed serum and urinary bile acids in Japanese infants with unexplained cholestasis since 1996.[7, 8] So far our 7 BASD patients include 3 with $3 \beta$-HSD deficiency, 3 with $5 \beta$-reductase deficiency, and 1 with oxysterol 7a deficiency.[7-11, 13]

In Europe and the United States (US), primary bile acid treatment using oral cholic acid (CA) is the first-

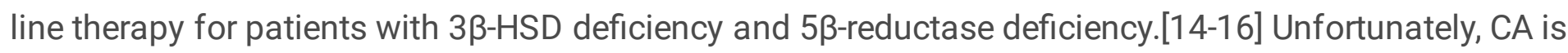
not available for clinical use in Japan. Given this restriction, we have treated 5 patients with $3 \beta$-HSD deficiency or $5 \beta$-reductase deficiency using oral chenodeoxycholic acid (CDCA) for more than 8 years.

Here we report the long-term outcomes and bile acid profiles in 7 Japanese patients with BASD. We also describe efficacy of long-term CDCA treatment in the 5 patients with $3 \beta$-HSD deficiency or $5 \beta$-reductase deficiency.

\section{Results}

\section{Long-term outcome}

Table 1 summarizes current clinical and laboratory features including long-term outcome for the 7 patients. Ages at the most recent visit ranged from 8 and 43 years (median, 10). Five patients, including 3 with $3 \beta$-HSD deficiency and 2 with $5 \beta$-reductase deficiency, had received long-term CDCA treatment (median, 10 years; range, 8 to 21 ). One patient with $5 \beta$-reductase deficiency was treated with ursodeoxycholic acid (UDCA) only during her first year, while early in life another patient who had oxysterol 7a deficiency required liver transplantation, which was successful. At most recent assessment, all patients were healthy without any treatment complications or other problems. Additionally, laboratory results and images showed normal results and no evidence of liver failure or cirrhosis. We did not perform follow-up liver biopsy in the patients because no symptoms or laboratory findings suggested liver dysfunction. All patients developed normally, falling within \pm 2 standard deviation (SD) for height and body weight. All patients received a general education, and all 2 were employed upon reaching adulthood.

Bile acid profiles in the 5 patients with CDCA treatment for a long-term 
Tables 2 and 3 respectively summarize bile acid profiles before and after CDCA treatment in 5 patients including 3 patients with $3 \beta-H S D$ deficiency and 2 with $5 \beta$-reductase deficiency who had undergone longterm CDCA treatment.

In the 5 CDCA-treated patients, percentages of unusual bile acids among serum and urinary TBA at the time of diagnosis were $87.5 \%$ or more except in serum from Patient 5 (Tables 2 and 3 ). Concentrations of unusual bile acids in serum and urine ranged from 2.4 to $25.1 \mu \mathrm{mol} / \mathrm{L}$ and 17.3 to $123.9 \mu \mathrm{mol} / \mathrm{mmol}$ creatinine $(\mathrm{Cr})$, respectively. During CDCA treatment in the 5 patients, percentages of serum unusual bile acids among TBA decreased expect for Patient 5 , while percentages of urinary unusual bile acids among TBA were more than $58.8 \%$ (Tables 2 and 3 ). Concentrations of serum and urinary unusual bile acids during CDCA treatment decreased to 0.1 to $5.7 \mu \mathrm{mol} / \mathrm{L}$ and 2.0 to $13.9 \mu \mathrm{mol} / \mathrm{mmol} \mathrm{Cr}$, respectively. CDCA treatment clearly reduced amounts of serum and urinary TBA in $3 \beta-H S D$ deficiency. Treated patients with $5 \beta$-reductase deficiency had normal liver function, but bile acid analysis using gas chromatography-mass spectrometry (GC-MS) did not show any clear improvement of unusual bile acids (Table 3 ).

In the 3 patients with $3 \beta$-HSD deficiency (Table 2), serum percentages of unusual bile acids (3ß-hydroxy$\triangle^{5}$ bile acids) among TBA were decreased by CDCA treatment. Since CDCA administration increased CDCA concentrations and percentages among TBAs, total TBA concentrations increased slightly. However, alanine aminotransferase (ALT) and direct bilirubin (D Bil) were in the normal range, and unusual bile acids ( $3 \beta$-hydroxy- $\Delta^{5}$ bile acids) decreased in serum concentrations and percentages among TBA.

As for the 2 patients with $5 \beta$-reductase deficiency who received CDCA (Table 3), treatment clearly decreased serum concentration of unusual bile acids (3-oxo- $\Delta^{4}$ bile acids) and their percentage among TBA in Patient 6 . Patient 5 showed an increase of serum concentration of unusual bile acids (3-oxo- $\Delta^{4}$ bile acids) and percentage of unusual bile acids among TBA. On the other hand, urinary concentrations of unusual bile acids (3-oxo- $\Delta^{4}$ bile acids) and TBA levels were clearly decreased in both patients. However, the percentage of urinary unusual bile acids (3-oxo- $\Delta^{4}$ bile acids) among TBA did not change.

Bile acid profiles in the patient with oxysterol 7a deficiency before and after liver transplantation

The patient with oxysterol 7a deficiency developed decompensated hepatocellular failure at the age of 8 months and underwent living donor liver transplantation.[11] After transplantation, unusual bile acids (3ß-monohydroxy $-\Delta^{5}$ bile acids) disappeared from both serum and urine, and TBA concentrations improved. Most recently, trace amounts of unusual bile acid were detected in serum and urine (Table 4), but no cholestasis or hepatic dysfunction have occurred. 
One patient (Patient 4) with 5 $\beta$-reductase deficiency who had never received CDCA showed jaundice at 4 weeks of age, which progressively worsened until 3 months of age, becoming deeply icteric with pale stools and dark urine. UDCA treatment ( $5 \mathrm{mg} / \mathrm{kg} /$ day) was started, after which serum bilirubin and aminotransferase concentrations gradually decreased (Supplementary Figure 1). When excessive 3-oxo$\Delta^{4}$ bile acids were detected (Table 5), we recommended primary bile acid treatment for a suspected BASD. Her parents declined, so we increased the dose of UDCA to $10 \mathrm{mg} / \mathrm{kg} / \mathrm{day}$. By 11 months of age, serum bilirubin and aminotransferase concentrations were within the normal range (Supplementary Figure 1). Untreated after her first year, Patient 4 has been in good health without liver dysfunction at follow-up visits from 15 months of age to the present, although hyper-3-oxo- $\Delta^{4}$ bile aciduria has continued with UDCA treatment. In a recent bile acid analysis (Table 5), serum and urinary TBA and unusual bile acids (3-oxo- $\Delta^{4}$ bile acids) appeared to be gradually decreasing. However, the percentage of unusual bile acids (3-oxo- $\Delta^{4}$ bile acids) among serum TBA remained high. This result was similar to findings in Patient 5, who has received CDCA treatment (Table 3).

\section{Discussion}

We identified long-term clinical and laboratory findings and bile acid profiles in 7 Japanese patients with BASD including 5 patients treated with CDCA and 1 with UDCA; the other patient underwent liver transplantation. All patients had improved liver dysfunction, freedom from treatment complications, normal growth and development, and absence of psychosocial problems. Accordingly, the long-term outcomes of these Japanese patients with BASD has been good.

In Europe and the US, 3ß-HSD deficiency is about 8 times more common than $5 \beta$-reductase deficiency.[1517] In Saudi Arabia, $2.7 \%$ of patients with cholestasis in infancy were found to have BASD.[18] In Japan, our bile acid analyses in 1010 infants with cholestasis lacking obvious cause between 1996 and 2017 showed a BASD prevalence of $0.7 \%$, with equal numbers of cases for $3 \beta-H S D$ deficiency and $5 \beta$ reductase deficiency. Our experience as well as previous reports from East Asia suggests that $3 \beta-H S D$ deficiency is less prevalent in East Asia than in Europe or the US.[8-11, 13, 19, 20] On the other hand, oxysterol 7a deficiency may be more prevalent in East Asia.[11, 21-23]

CA (10 to $15 \mathrm{mg} / \mathrm{kg} /$ day) has been approved in Europe and the US for treating patients with $3 \beta-H S D$ deficiency and $5 \beta$-reductase deficiency, making it the primary bile acid therapy for these BASD in most of the West.[14-17] In particular, CA has a very good therapeutic effect in 3ß-HSD deficiency. However, CA monotherapy is insufficient for $5 \beta$-reductase deficiency.[18] UDCA treatment is used initially until a diagnosis of $5 \beta$-reductase deficiency is made. In early infancy, $5 \beta$-reductase deficiency may be exacerbated by CA. In some instances, liver failure may ensue even after CA treatment is started. In consideration of reported mortality, CDCA typically is used in combination with CA to increase the therapeutic effect.[17, 18, 24] In Japan, CDCA is used instead of CA for treatment of BASD, since the latter is not available for clinical use in Japan; the same is true for China.[25] We have obtained a reliable 
therapeutic effect from CDCA, and believe that a low dose of CDCA (5 to $10 \mathrm{mg} / \mathrm{kg} / \mathrm{day}$ ) can obtain sufficient benefit.[10, 13] Low doses are particularly important because CDCA is more hepatotoxic than CA. CDCA as a treatment for $3 \beta$-HSD deficiency and $5 \beta$-reductase deficiency has been described in previous reports. $[24,26]$ We consider low-dose CDCA to be effective in both $3 \beta$-HSD deficiency and $5 \beta$ reductase deficiency making this treatment particularly important where CA is not available. If CA obtains approval in Japan, we would like to use it in $3 \beta-H S D$ deficiency and $5 \beta$-reductase deficiency, but we believe that patients in East Asia might require only a low dose of CA (5 to $10 \mathrm{mg} / \mathrm{kg} / \mathrm{day}$ ) as opposed to the doses up to $15 \mathrm{mg} / \mathrm{kg} /$ day that often are given in Europe and the US.

Before CDCA treatment in our 3 patients with 3 $\beta$-HSD deficiency, unusual bile acids accounted for $87.5 \%$ to $100 \%$ and $94 \%$ to $100 \%$ of serum and urinary bile acids, respectively; for our 2 patients with $5 \beta$ reductase deficiency, these respective percentages were $54.7 \%$ to $91.6 \%$ and $98.4 \%$ to $99.7 \%$ (Tables 2 and 3). During treatment, percentages of unusual bile acids among serum TBA decreased except in Patient 5; in urine, however, these percentages remained high (Tables 2 and 3 ). However, the concentration of unusual bile acids in urine clearly decreased. In our study, details of bile acid dynamics in hepatocytes are not known, but liver function in our patients improved. This suggests that CDCA treatment suppressed synthesis of unusual bile acids, while the remaining unusual bile acids were excreted via the kidneys. During CDCA treatment, the decreasing concentrations of unusual bile acids in serum and urine resulted from a negative feedback effect by CDCA upon hepatocytic CYP7A1. Concentrations of unusual bile acids in serum decreased except in Patient 5 , and hepatic function improved. Given the renal excretion, evaluation of unusual bile acids during CDCA treatment requires bile acid analysis in serum and urine by GC-MS rather than simply determining the percentage of unusual bile acids among urinary TBA. Both concentrations and percentages of unusual bile acids in serum obtained by this analytic method are necessary.

Bile acid analysis showed disappearance of unusual bile acids immediately after liver transplantation in our patient with oxysterol 7a deficiency (Table 4). Recent reports described that oxysterol 7a deficiency can be treated with CDCA treatment.[23,27] Since liver function rapidly deteriorates in oxysterol $7 a$ deficiency, early diagnosis and initiation of CDCA therapy are particularly urgent.

The somewhat enigmatic Patient 4 in Table 5 was diagnosed with $5 \beta$-reductase deficiency based on bile acid profiles and genetic analysis. Based on parental wishes, she was treated only with UDCA, which was discontinued at 12 months of age when her liver function had fully recovered and she was free of symptoms. With no treatment, this healthy state has continued through the most recent follow-up at 16 years. We speculate that her favorable course might be related to the small amounts of allo-bile acids, such as allo-cholic acid and allo-chenodeoxycholic acid, detected in serum and urine (Table 5). Allo-bile acids presumably are synthesized from 3-oxo- $\Delta^{4}$-bile acids, which normally would be transformed to $5 \beta$ bile acids by $5 \beta$-reductase. Fortunately, the toxicity of allo-cholic acid is only on a par with that of cholic acid.[28] Allo-bile acids also are efficiently excreted into the bile via transport systems apart from the bile salt export pump, such as multidrug resistance protein 2 (MRP2).[28, 29] This would account for the very limited quantities of allo-bile acids in the patient's serum and urine. For this reason, fat-soluble vitamin 
deficiency and other symptoms have not occurred since discontinuation of treatment. In general, however, allo-bile acids in excess of 3-oxo- $\Delta^{4}$-bile acids can cause significant liver dysfunction.

Unlike allo-bile acids, ketonic bile acids (3-oxo- $\Delta^{4}$-bile acids) are highly toxic to hepatocytes and difficult to excrete into bile.[2] Many ketonic bile acids are discharged into the blood via MRP3 on the basolateral membrane of hepatocytes, followed by renal excretion.[30] Larger amounts of ketonic bile acids in urine than in serum therefore are found. This excretion mechanism increases in activity during late infancy. These findings resemble those that we have seen in bile acid analyses at the beginning of primary bile acid (CDCA) treatment for BASD such as $5 \beta$-reductase deficiency. However, at this time the proportions of therapeutically administered bile acids, such as cholic acid and/or chenodeoxycholic acid, increase. Large amounts of 3-oxo- $\Delta^{4}$-bile acids therefore found in serum and urine in neonates and younger infants with $5 \beta$-reductase deficiency, while later in infancy 3-oxo- $\Delta^{4}$-bile acids gradually decrease in serum but are abundant in urine. In neonates and young infants with $5 \beta$-reductase deficiency, cholestatic liver dysfunction becomes evident, and primary bile acid treatment is necessary. On the other hand, primary bile acid treatment sometimes may not be required after 1 year of age. Allo-bile acids are excreted into bile via MRP2. Ketonic bile acids are transported into the blood via MRP3 and then excreted by the kidneys. Activity of MRP3 increases during infancy, equaling that in an adult at about 1 year. At that point, if ketonic bile acids are excreted adequately, liver function improves and primary bile acid treatment might be no longer be necessary. In another patient with 5ß-reductase deficiency (Patient 5 in Table 3), discontinuation of primary bile acid treatment for 1 month did not adversely affect liver function.[10]

In summary, we believe that $3 \beta$-HSD deficiency, which is not common in East Asia, should be adequately treatable with CA given that disease progression is slow. In contrast, $5 \beta$-reductase deficiency and oxysterol 7a deficiency rapidly progress to liver cirrhosis or cholestatic liver failure in infancy. We therefore believe that in infancy, prompt treatment with CDCA or a combination of CA and CDCA is needed for patients with $5 \beta$-reductase deficiency, as also is true for oxysterol 7 a deficiency. We believe that primary bile acid treatment is necessary for $5 \beta$-reductase deficiency in infancy. After 6 months to 1 year, follow-up treatment with UDCA or cessation of treatment might be considered. However, further study is needed, since phenotypes differ depending on specific genotypes of SRD5B1. To our knowledge, this is the first report of long-term outcome and efficacy of CDCA treatment in a group of patients with BASD from East Asia.

\section{Conclusion}

We believe that low-dose CDCA ( 5 to $10 \mathrm{mg} / \mathrm{kg} /$ day) is useful for treating BASD including $3 \beta$-HSD deficiency and $5 \beta$-reductase deficiency, as has been shown for CA (10 to $15 \mathrm{mg} / \mathrm{kg} /$ day) treatment. BASD have a good prognosis following early diagnosis and low-dose CDCA treatment.

\section{Methods}

Patients 
All 7 patients were previously reported. Diagnoses were made from bile acid profiles and genetic analyses by Sanger sequencing. These patients included 3 with $3 \beta$-HSD deficiency, 3 with $5 \beta$-reductase deficiency, and 1 with oxysterol 7a deficiency.[8-11, 13] Two patients with 5 $\beta$-reductase deficiency, initially found to have only a heterozygous mutation in the $S R D 5 B 1$ gene, $[9,10]$ subsequently were re-analyzed by targeted next-generation sequencing [31] that identified compound heterozygous mutations in the SRD5B1 gene. Patient characteristics and laboratory results at diagnosis, gene mutations, and diagnosis are shown in Table 6. $[7-11,13]$ Our study protocols were approved by the ethics committees at Kurume University and Nagoya City University Graduate School of Medical Sciences. Written informed consent was obtained from enrolled patients or their parents.

\section{Long-term clinical and laboratory findings}

Clinical and laboratory findings at the most recent visit were retrospectively obtained from medical records. Long-term outcome included follow-up duration, treatments, growth, education/employment, complications of treatment, and other problems. Growth was evaluated by height and weight, expressed in terms of SD.[32] Other assessments included serum GGT, ALT, D Bil, TBA using 3a-hydroxysteroid dehydrogenase enzyme method, and also tests for liver failure or cirrhosis including complete blood count, coagulation factors, and abdominal ultrasonography.

\section{Bile acid profiles}

In bile acid analysis, serum and urine samples were collected and stored below $-20^{\circ} \mathrm{C}$ until analysis. Concentrations of individual bile acids in the urine were corrected for the $\mathrm{Cr}$ concentration and expressed as $\mu \mathrm{mol} / \mathrm{mmol} \mathrm{Cr}$. By comparison with control standard samples that we synthesized to represent specific unusual bile acids such as $3 \beta$-hydroxy- $\Delta^{5}, 3-0 x 0-\Delta^{4}$ and allo-bile acids, which occur in BASD, we analyzed bile acids in the patients' urine and serum using GC-MS with monitoring of selected ions. Specifically, we selectively monitored characteristic ionic fragments of methyl ester-dimethylethylsilyl ether-methoxime derivatives of bile acids after enzymatic hydrolysis (choloylglycine hydrolase, 30 units) and solvolysis (sulfatase, 150 units; Sigma, St Louis, MO, USA), as described previously.[33]

Using the above analytic method, we performed bile acid analysis in the enrolled patients at the time of diagnosis and follow-up evaluations including the most current visit.

\section{Abbreviations}

BASD, bile acid synthesis disorders ; $3 \beta$-HSD, $3 \beta$-hydroxy- $\Delta^{5}-C_{27}$-steroid dehydrogenase/isomerase; $5 \beta$ reductase, $\Delta^{4}$-3-oxosteroid $5 \beta$-reductase; oxysterol 7a, oxysterol 7a-hydroxylase; GGT, Y- $^{-}$ 
glutamyltransferase; TBA, total bile acids; United States, US; CA, cholic acid; CDCA, chenodeoxycholic acid; UDCA, ursodeoxycholic acid; SD, standard deviation; Cr, creatinine; GC-MS, gas chromatographymass spectrometry; ALT, alanine aminotransferase; D Bil, direct bilirubin; MRP, multidrug resistance protein.

\section{Declarations}

\section{Ethics approval and consent to participate}

This study was approved by the ethics committees at Kurume University and Nagoya City University Graduate School of Medical Sciences. Written informed consent was obtained from enrolled patients or their parents.

\section{Consent for publication}

Written informed consent was obtained from enrolled patients or their parents.

\section{Availability of data and materials}

The datasets used and/or during the current study are available from the corresponding author on reasonable request.

\section{Competing interests}

We have no competing interests.

\section{Funding}

We have no financial support.

Authors' contributions: Concept and design of study, AK, TMi and HN; acquisition of samples and data, $\mathrm{AK}, \mathrm{TMi}, \mathrm{HT}, \mathrm{AO}, \mathrm{JM}, \mathrm{TH}, \mathrm{MK}$, and HN; bile acid analysis, $\mathrm{HT}$ and $\mathrm{HN}$; genetic analysis, TMi and TT; 
synthesis of standard bile acid samples, TMu and Tl; interpretation of data and drafting of the article, AK and TMi; critical review and approval of the draft, all authors.

\section{Acknowledgments}

The authors thank all participating patients, their families, and physicians and surgeons for collaborating in data collection.

\section{References}

1. Clayton PT, Leonard JV, Lawson AM, Setchell KD, Andersson S, Egestad B, et al. Familial giant cell hepatitis associated with synthesis of 3 beta, 7 alpha-dihydroxy-and 3 beta,7 alpha, 12 alphatrihydroxy-5-cholenoic acids. J Clin Invest 1987;79(4):1031-8.

2. Setchell KD, Suchy FJ, Welsh MB, Zimmer-Nechemias L, Heubi J, Balistreri WF. Delta 4-3-oxosteroid 5 beta-reductase deficiency described in identical twins with neonatal hepatitis. A new inborn error in bile acid synthesis. J Clin Invest 1988;82(6):2148-57.

3. Setchell KD, Schwarz M, O'Connell NC, Lund EG, Davis DL, Lathe R, et al. Identification of a new inborn error in bile acid synthesis: mutation of the oxysterol 7alpha-hydroxylase gene causes severe neonatal liver disease. J Clin Invest 1998;102(9):1690-703.

4. Clayton PT, Verrips A, Sistermans E, Mann A, Mieli-Vergani G, Wevers R. Mutations in the sterol 27hydroxylase gene (CYP27A) cause hepatitis of infancy as well as cerebrotendinous xanthomatosis. $J$ Inherit Metab Dis 2002;25(6):501-13.

5. Chong CP, Mills PB, McClean P, Gissen P, Bruce C, Stahlschmidt J, et al. Bile acid-CoA ligase deficiency-a new inborn error of bile acid metabolism. J Inherit Metab Dis 2012;35(3):521-30.

6. Setchell KD, Heubi JE, Shah S, Lavine JE, Suskind D, Al-Edreesi M, et al. Genetic defects in bile acid conjugation cause fat-soluble vitamin deficiency. Gastroenterology 2013;144(5):945-55.e6; quiz e145.

7. Terazawa S, Kimura A, Inoue T, Murai T, Kurosawa T, Takao A. An infant with 3 beta-hydroxy-delta 5C27-steroid dehydrogenase/isomerase deficiency presenting with typical neonatal hepatitis syndrome: the first Japanese case. Acta Paediatr Jpn 1998;40(6):638-40.

8. Nittono $H$, Takei $H$, Unno A, Shimizu T, Kobayashi M, Koike M, et al. 3beta-hydroxy-Delta5-C27-steroid dehydrogenase/isomerase deficiency in a patient who underwent oral bile acid therapy for 10 years and delivered two healthy infants. Pediatr Int 2010;52(4):e192-5.

9. Ueki I, Kimura A, Chen HL, Yorifuji T, Mori J, Itoh S, et al. SRD5B1 gene analysis needed for the accurate diagnosis of primary 3-oxo-Delta4-steroid 5beta-reductase deficiency. J Gastroenterol 
Hepatol 2009;24(5):776-85.

10. Seki Y, Mizuochi T, Kimura A, Takahashi T, Ohtake A, Hayashi S, et al. Two neonatal cholestasis patients with mutations in the SRD5B1 (AKR1D1) gene: diagnosis and bile acid profiles during chenodeoxycholic acid treatment. J Inherit Metab Dis 2013;36(3):565-73.

11. Mizuochi T, Kimura A, Suzuki M, Ueki I, Takei H, Nittono H, et al. Successful heterozygous living donor liver transplantation for an oxysterol 7alpha-hydroxylase deficiency in a Japanese patient. Liver Transpl 2011;17(9):1059-65.

12. Clayton PT. Disorders of bile acid synthesis. J Inherit Metab Dis 2011;34(3):593-604.

13. Mizuochi T, Kimura A, Ueki I, Takahashi T, Hashimoto T, Takao A, et al. Molecular genetic and bile acid profiles in two Japanese patients with 3beta-hydroxy-DELTA5-C27-steroid dehydrogenase/isomerase deficiency. Pediatr Res 2010;68(3):258-63.

14. Heubi JE, Bove KE, Setchell KDR. Oral Cholic Acid Is Efficacious and Well Tolerated in Patients With Bile Acid Synthesis and Zellweger Spectrum Disorders. J Pediatr Gastroenterol Nutr 2017;65(3):3216.

15. Gonzales E, Gerhardt MF, Fabre M, Setchell KD, Davit-Spraul A, Vincent I, et al. Oral cholic acid for hereditary defects of primary bile acid synthesis: a safe and effective long-term therapy. Gastroenterology 2009;137(4):1310-20.e1-3.

16. Gonzales E, Matarazzo L, Franchi-Abella S, Dabadie A, Cohen J, Habes D, et al. Cholic acid for primary bile acid synthesis defects: a life-saving therapy allowing a favorable outcome in adulthood. Orphanet J Rare Dis 2018;13(1):190.

17. Jahnel J, Zohrer E, Fischler B, D'Antiga L, Debray D, Dezsofi A, et al. Attempt to Determine the Prevalence of Two Inborn Errors of Primary Bile Acid Synthesis: Results of a European Survey. J Pediatr Gastroenterol Nutr 2017;64(6):864-8.

18. Al-Hussaini AA, Setchell KDR, AISaleem B, Heubi JE, Lone K, Davit-Spraul A, et al. Bile Acid Synthesis Disorders in Arabs: A 10-year Screening Study. J Pediatr Gastroenterol Nutr 2017;65(6):613-20.

19. Zhao J, Fang LJ, Setchell KD, Chen R, Li LT, Wang JS. Primary 4-3-oxosteroid 5beta-reductase deficiency: two cases in China. World J Gastroenterol 2012;18(47):7113-7.

20. Wang HH, Wen FQ, Dai DL, Wang JS, Zhao J, Setchell KD, et al. Infant cholestasis patient with a novel missense mutation in the AKR1D1 gene successfully treated by early adequate supplementation with chenodeoxycholic acid: A case report and review of the literature. World $\mathrm{J}$ Gastroenterol 2018;24(35):4086-92.

21. Ueki I, Kimura A, Nishiyori A, Chen HL, Takei H, Nittono H, et al. Neonatal cholestatic liver disease in an Asian patient with a homozygous mutation in the oxysterol 7alpha-hydroxylase gene. J Pediatr Gastroenterol Nutr 2008;46(4):465-9.

22. Hong J, Oh SH, Yoo HW, Nittono H, Kimura A, Kim KM. Complete Recovery of Oxysterol 7alphaHydroxylase Deficiency by Living Donor Transplantation in a 4-Month-Old Infant: the First Korean Case Report and Literature Review. J Korean Med Sci 2018;33(51):e324. 
23. Chen JY, Wu JF, Kimura A, Nittono H, Liou BY, Lee CS, et al. AKR1D1 and CYP7B1 mutations in patients with inborn errors of bile acid metabolism: Possibly underdiagnosed diseases. Pediatr Neonatol 2019.

24. Clayton PT, Mills KA, Johnson AW, Barabino A, Marazzi MG. Delta 4-3-oxosteroid 5 beta-reductase deficiency: failure of ursodeoxycholic acid treatment and response to chenodeoxycholic acid plus cholic acid. Gut 1996;38(4):623-8.

25. Zhang MH, Setchell KD, Zhao J, Gong JY, Lu Y, Wang JS. Delta4-3-oxosteroid-5beta-reductase deficiency: Responses to oral bile acid therapy and long-term outcomes. World J Gastroenterol 2019;25(7):859-69.

26. Ichimiya H, Nazer H, Gunasekaran T, Clayton P, Sjovall J. Treatment of chronic liver disease caused by 3 beta-hydroxy-delta 5-C27-steroid dehydrogenase deficiency with chenodeoxycholic acid. Arch Dis Child 1990;65(10):1121-4.

27. Dai D, Mills PB, Footitt E, Gissen P, McClean P, Stahlschmidt J, et al. Liver disease in infancy caused by oxysterol 7 alpha-hydroxylase deficiency: successful treatment with chenodeoxycholic acid. J Inherit Metab Dis 2014;37(5):851-61.

28. Mendoza ME, Monte MJ, Serrano MA, Pastor-Anglada M, Stieger B, Meier PJ, et al. Physiological characteristics of allo-cholic acid. J Lipid Res 2003;44(1):84-92.

29. Morikawa A, Goto Y, Suzuki H, Hirohashi T, Sugiyama Y. Biliary excretion of 17beta-estradiol 17betaD-glucuronide is predominantly mediated by cMOAT/MRP2. Pharm Res 2000;17(5):546-52.

30. Yamaguchi K, Murai T, Yabuuchi H, Kurosawa T. Measurement of transport activities of bile acids in human multidrug resistance-associated protein 3 using liquid chromatography-tandem mass spectrometry. Anal Sci 2010;26(3):317-23.

31. Togawa T, Sugiura T, Ito K, Endo T, Aoyama K, Ohashi K, et al. Molecular Genetic Dissection and Neonatal/Infantile Intrahepatic Cholestasis Using Targeted Next-Generation Sequencing. J Pediatr 2016;171:171-7.e1-4.

32. Isojima T, Kato N, Ito Y, Kanzaki S, Murata M. Growth standard charts for Japanese children with mean and standard deviation (SD) values based on the year 2000 national survey. Clin Pediatr Endocrinol 2016;25(2):71-6.

33. Kimura A, Mahara R, Inoue T, Nomura Y, Murai T, Kurosawa T, et al. Profile of urinary bile acids in infants and children: developmental pattern of excretion of unsaturated ketonic bile acids and 7betahydroxylated bile acids. Pediatr Res 1999;45(4 Pt 1):603-9.

\section{Tables}


Table 1. Current clinical and laboratory findings in 7 patients with BASD

\begin{tabular}{|c|c|c|c|c|c|c|c|}
\hline $\begin{array}{l}\text { Patient } \\
\text { No. }\end{array}$ & Age & $\begin{array}{l}\text { GGT / } \\
\text { ALT } \\
(\mathrm{U} / \mathrm{L})\end{array}$ & $\begin{array}{c}\text { D Bil / TBA } \\
(\mathrm{mg} / \mathrm{dL}) / \\
(\mu \mathrm{mol} / \mathrm{L})\end{array}$ & $\begin{array}{l}\text { Current treatment } \\
\text { and duration }\end{array}$ & (SD) & Height / Weight & $\begin{array}{l}\text { Education / } \\
\text { Employment }\end{array}$ \\
\hline \multicolumn{8}{|c|}{$\begin{array}{c}3 \beta \text {-HSD } \\
\text { deficiency }\end{array}$} \\
\hline 1 & $21 \mathrm{yr}$ & $\begin{array}{l}\text { not done } \\
\quad / 16\end{array}$ & $\begin{array}{l}1.0 / \text { not } \\
\text { done }\end{array}$ & $\begin{array}{c}\text { CDCA (4.0 } \\
\mathrm{mg} / \mathrm{kg} / \text { day) } \\
\text { continued for } 19 \\
\text { years }\end{array}$ & & $-0.5 /-0.2$ & $\begin{array}{c}\text { General } \\
\text { education / } \\
\text { Employed }\end{array}$ \\
\hline 2 & $43 \mathrm{yr}$ & $19 / 25$ & $0.3 / 4.9$ & $\begin{array}{c}\text { CDCA (7.8 } \\
\text { mg/kg/day) } \\
\text { continued for } 21 \\
\text { years }\end{array}$ & & $-1.4 / 1.8$ & $\begin{array}{c}\text { General } \\
\text { education / } \\
\text { Employed }\end{array}$ \\
\hline 3 & $10 \mathrm{yr}$ & $18 / 16$ & $0.1 / 7.6$ & $\begin{array}{c}\text { CDCA (4.6 } \\
\mathrm{mg} / \mathrm{kg} / \text { day) } \\
\text { continued for } 10 \\
\text { years }\end{array}$ & & $1.7 / 1.0$ & $\begin{array}{l}\text { General } \\
\text { education }\end{array}$ \\
\hline \multicolumn{8}{|c|}{$\begin{array}{c}5 \beta \text {-Reductase } \\
\text { deficiency }\end{array}$} \\
\hline 4 & $16 \mathrm{yr}$ & $9 / 8$ & $0.2 / 1.6$ & $\begin{array}{l}\text { No current } \\
\text { treatment }\end{array}$ & & $-1.5 /-0.7$ & $\begin{array}{l}\text { General } \\
\text { education }\end{array}$ \\
\hline 5 & $8 \mathrm{yr}$ & $11 / 11$ & $0.1 / 3.0$ & $\begin{array}{c}\text { CDCA (4.1 } \\
\mathrm{mg} / \mathrm{kg} / \text { day) } \\
\text { continued for } 8 \\
\text { years }\end{array}$ & & $0.8 /-0.3$ & $\begin{array}{l}\text { General } \\
\text { education }\end{array}$ \\
\hline 6 & $8 \mathrm{yr}$ & $17 / 12$ & $0.1 / 2.2$ & $\begin{array}{c}\text { CDCA (5.4 } \\
\text { mg/kg/day) } \\
\text { continued for } 8 \\
\text { years }\end{array}$ & & $-0.4 /-0.6$ & $\begin{array}{c}\text { General } \\
\text { education }\end{array}$ \\
\hline \multicolumn{8}{|c|}{$\begin{array}{c}\text { Oxysterol } 7 \alpha \\
\text { deficiency }\end{array}$} \\
\hline 7 & $10 \mathrm{yr}$ & $16 / 14$ & $0.2 / 4.1$ & $\begin{array}{c}\text { Immunomodulator } \\
\text { after liver } \\
\text { transplantation }\end{array}$ & & $1.6 / 1.0$ & $\begin{array}{l}\text { General } \\
\text { education }\end{array}$ \\
\hline Median & $10 \mathrm{yr}$ & $16.5 / 14$ & $0.2 / 3.6$ & & & $-0.4 /-0.2$ & \\
\hline (Range) & $\begin{array}{l}\text { (8 to } \\
43)\end{array}$ & $\begin{array}{l}(9 \text { to } 19 / \\
8 \text { to } 25)\end{array}$ & $\begin{array}{l}\text { (0.1 to } 1.0 / \\
1.6 \text { to } 4.9)\end{array}$ & & & (-1.5 to $1.7 /-0.7$ to 1.8$)$ & \\
\hline
\end{tabular}

BASD, bile acid synthesis disorders; GGT, $\gamma$-glutamyltransferase; ALT, alanine aminotransferase; D.Bil, direct bilirubin; TBA, serum total bile acids

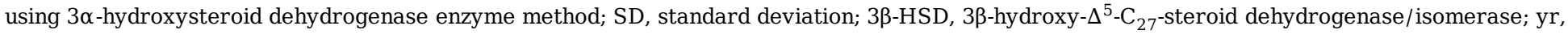
years; CDCA, chenodeoxycholic acid; $5 \beta$-reductase, $\Delta^{4}$-3-oxosteroid $5 \beta$-reductase; oxysterol $7 \alpha$, oxysterol $7 \alpha$-hydroxylase. 
Table 2. Bile acid profiles in patients with 3B-HSD deficiency before and during CDCA treatment

\begin{tabular}{|c|c|c|c|c|c|c|}
\hline & \multicolumn{2}{|c|}{ Patient 1} & \multicolumn{2}{|c|}{ Patient 2} & \multicolumn{2}{|c|}{ Patient 3} \\
\hline & before & during CDCA & before & during CDCA & before & during CDCA \\
\hline Age & 18 moths & 21 years & 22 years & 43 years & 6 moths & 10 years \\
\hline \multicolumn{7}{|l|}{ Serum $(\mu \mathrm{mol} / \mathrm{L})$} \\
\hline CA & 0.7 & n.d. & - & 0.1 & n.d. & n.d. \\
\hline CDCA & 0.4 & 17.2 & - & 11.6 & n.d. & 8.8 \\
\hline UDCA & n.d. & 12.0 & - & 6.4 & n.d. & 3.4 \\
\hline $3 \beta$-Hydroxy- $\Delta^{5}$ bile acids & $7.7(87.5 \%)$ & $4.3(12.8 \%)$ & - & $1.6(7.4 \%)$ & $2.4(35.8 \%)$ & $5.7(24.7 \%)$ \\
\hline Others & trace & 0.2 & - & 1.7 & $4.3 *(64.2 \%)$ & 5.2 \\
\hline Total bile acids & 8.8 & 33.7 & - & 21.4 & 6.7 & 23.1 \\
\hline \multicolumn{7}{|l|}{ Urine ( $\mu \mathrm{mol} / \mathrm{mmol}$ creatinine) } \\
\hline $\mathrm{CA}$ & 0.8 & n.d. & n.d. & n.d. & n.d. & n.d. \\
\hline CDCA & 1.4 & trace & 0.3 & 0.1 & n.d. & 0.1 \\
\hline UDCA & 0.1 & 0.3 & 0.3 & 1.1 & n.d. & 2.0 \\
\hline $3 \beta$-Hydroxy- $\Delta^{5}$ bile acids & $63.2(94.0 \%)$ & $3.6(90.0 \%)$ & $38.4(98.5 \%)$ & $2.0(58.8 \%)$ & $1.7(9.8 \%)$ & $13.9(84.2 \%)$ \\
\hline Others & 1.7 & 0.1 & n.d. & 0.2 & $15.6 *(90.2 \%)$ & 0.5 \\
\hline Total bile acids & 67.2 & 4.0 & 39.0 & 3.4 & 17.3 & 16.5 \\
\hline
\end{tabular}

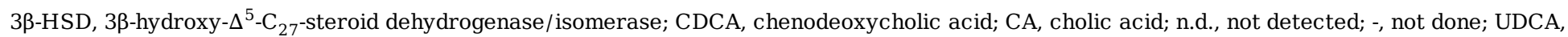

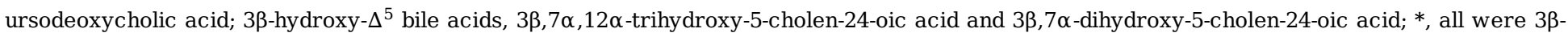
hydroxy-5-cholen 24-oic acid. 
Table 3. Bile acid profiles in patients with $5 \beta$-reductase deficiency before and during CDCA treatment

\begin{tabular}{|c|c|c|c|c|}
\hline & \multicolumn{2}{|c|}{ Patient 5} & \multicolumn{2}{|c|}{ Patient 6} \\
\hline & before & during CDCA & before & during CDCA \\
\hline Age & 6 months & 8 years & 9 months & 8 years \\
\hline \multicolumn{5}{|l|}{ Serum $(\mu \mathrm{mol} / \mathrm{L})$} \\
\hline $\mathrm{CA}$ & n.d. & trace & n.d. & n.d. \\
\hline CDCA & 0.1 & 1.3 & n.d. & 1.0 \\
\hline UDCA & 1.5 & n.d. & n.d. & 0.3 \\
\hline Allo-bile acids & $0.9(17.0 \%)$ & $0.2(3.8 \%)$ & n.d. & trace \\
\hline 3-Oxo- $\Delta^{4}$ bile acids & $2.0(37.7 \%)$ & $3.7(69.8 \%)$ & $25.1(91.6 \%)$ & $0.1(7.1 \%)$ \\
\hline Others & 0.8 & 0.1 & 2.3 & trace \\
\hline Total bile acids & 5.3 & 5.3 & 27.4 & 1.4 \\
\hline \multicolumn{5}{|c|}{ Urine ( $\mu \mathrm{mol} / \mathrm{mmol}$ creatinine) } \\
\hline $\mathrm{CA}$ & 0.2 & trace & n.d. & n.d. \\
\hline CDCA & n.d. & trace & n.d. & trace \\
\hline UDCA & 0.9 & trace & n.d. & 0.1 \\
\hline Allo-bile acids & 0.8 & 0.1 & n.d. & n.d. \\
\hline 3-Oxo- $\Delta^{4}$ bile acids & $123.9(98.4 \%)$ & $4.4(89.8 \%)$ & $58.9(99.7 \%)$ & $3.5(94.6 \%)$ \\
\hline Others & 0.1 & 0.4 & 0.2 & 0.1 \\
\hline Total bile acids & 125.9 & 4.9 & 59.1 & 3.7 \\
\hline
\end{tabular}

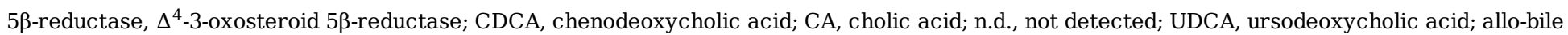
acids, allo-cholic acid and allo-chenodeoxycholic acid; 3-oxo- $\Delta^{4}$ bile acids, $7 \alpha, 12 \alpha$-dihydroxy-3-oxo-4-cholenoic acid and $7 \alpha$-hydroxy-3-oxo-4cholenoic acid. 
Table 4. Bile acid profiles in Patient 7 with oxysterol $7 \alpha$ deficiency before and after liver transplantation

\begin{tabular}{|c|c|c|c|c|}
\hline & before LT & & after LT & \\
\hline Age & 6 months & 9 months & 28 months & 10 years \\
\hline \multicolumn{5}{|l|}{ Serum $(\mu \mathrm{mol} / \mathrm{L})$} \\
\hline $\mathrm{CA}$ & n.d. & 7.6 & - & 0.6 \\
\hline CDCA & 1.1 & 2.1 & - & 2.1 \\
\hline UDCA & 21.2 & 6.5 & - & 0.8 \\
\hline $3 \beta$-Hydroxy-5-cholen 24-oic acid & $7.3^{*}$ & n.d. & - & $0.2(5 \%)$ \\
\hline Others & 0.2 & n.d. & - & 0.3 \\
\hline Total bile acids & 29.8 & 16.2 & - & 4.0 \\
\hline \multicolumn{5}{|l|}{ Urine ( $\mu \mathrm{mol} / \mathrm{mmol}$ creatinine) } \\
\hline $\mathrm{CA}$ & 3.5 & 0.2 & 0.2 & trace \\
\hline CDCA & 1.3 & trace & trace & 0.1 \\
\hline UDCA & 59.2 & 1.3 & 1.3 & 0.4 \\
\hline 3ß-Hydroxy-5-cholen 24-oic acid & $41.7^{* *}$ & n.d. & n.d. & $0.3(20 \%)$ \\
\hline Others & 4.0 & 0.1 & 0.1 & 0.7 \\
\hline Total bile acids & 109.7 & 1.6 & 1.6 & 1.5 \\
\hline
\end{tabular}

oxysterol 7 $\alpha$, oxysterol $7 \alpha$-hydroxylase; LT, liver transplantation; CA, cholic acid; n.d., not detected; -, not done; CDCA, chenodeoxycholic acid; UDCA, ursodeoxycholic acid; *, The percentages among serum total bile acids with and without UDCA were $24.5 \%$ and $84.9 \%$, respectively; $* *$, The percentages among urinary total bile acids with and without UDCA were $38.0 \%$ and $82.9 \%$, respectively; This patient had received UDCA treatment before 10 years of age. 
Table 5. Bile acid profiles in Patient 4 with 5 $\beta$-reductase deficiency during and after UDCA treatment

\begin{tabular}{|c|c|c|c|}
\hline \multirow[b]{2}{*}{ Age } & \multirow{2}{*}{$\begin{array}{c}\text { during UDCA } \\
8 \text { months }\end{array}$} & \multicolumn{2}{|c|}{ no treatment } \\
\hline & & 12 months & 16 years \\
\hline \multicolumn{4}{|l|}{ Serum $(\mu \mathrm{mol} / \mathrm{L})$} \\
\hline CA & n.d. & 0.1 & trace \\
\hline CDCA & n.d. & 0.7 & 1.3 \\
\hline UDCA & 2.9 & n.d. & n.d. \\
\hline Allo-bile acids & n.d. & $4.4(44.9 \%)$ & $0.2(3.8 \%)$ \\
\hline 3 -Oxo- $\Delta^{4}$ bile acids & $5.6(65.9 \%)$ & $2.4(24.4 \%)$ & $3.7(69.8 \%)$ \\
\hline Others & trace & 2.2 & 0.1 \\
\hline Total bile acids & 8.5 & 9.8 & 5.3 \\
\hline \multicolumn{4}{|l|}{ Urine ( $\mu \mathrm{mol} / \mathrm{mmol}$ creatinine) } \\
\hline CA & 0.7 & 2.4 & trace \\
\hline CDCA & 0.7 & 0.1 & n.d. \\
\hline UDCA & 29.3 & n.d. & trace \\
\hline Allo-bile acids & n.d. & 0.3 & $0.1(0.3 \%)$ \\
\hline 3-Oxo- $\Delta^{4}$ bile acids & $133.6(79.0 \%)$ & $107.4(94.1 \%)$ & $30.6(97.1 \%)$ \\
\hline Others & 4.9 & 3.9 & 0.8 \\
\hline Total bile acids & 169.2 & 114.1 & 31.5 \\
\hline
\end{tabular}

$5 \beta$-reductase, $\Delta^{4}$-3-oxosteroid 5ß-reductase; UDCA, ursodeoxycholic acid; CA, cholic acid; n.d., not detected; CDCA, chenodeoxycholic acid; altobile acids, allo-cholic acid and allo-chenodeoxycholic acid; 3-oxo- $\Delta^{4}$ bile acids, $7 \alpha, 12 \alpha$-dihydroxy-3-oxo-4-cholenoic acid and $7 \alpha$-hydroxy-3-oxo-4cholenoic acid. 
Table 6. Characteristics at diagnosis in 7 patients with BASD

\begin{tabular}{|c|c|c|c|c|c|c|c|}
\hline $\begin{array}{l}\text { Patient } \\
\text { No. }\end{array}$ & Age & Gender & $\begin{array}{c}\text { GGT / ALT } \\
(\mathrm{U} / \mathrm{L})\end{array}$ & $\begin{array}{c}\text { D Bil / TBA } \\
(\mathrm{mg} / \mathrm{dL}) / \\
(\mu \mathrm{mol} / \mathrm{L})\end{array}$ & Mutations & Diagnosis & $\begin{array}{l}\text { Ref. } \\
\text { No. }\end{array}$ \\
\hline 1 & $18 \mathrm{mo}$ & $\mathrm{M}$ & $23 / 596$ & $5.9 / 2.5$ & $\begin{array}{c}\text { homozygous in } H S D 3 B 7 \\
\text { c.314 del A }\end{array}$ & 3ß-HSD deficiency & 7,13 \\
\hline 2 & $22 \mathrm{yr}$ & $\mathrm{F}$ & $27 / 45$ & $4.5 / 4.1$ & $\begin{array}{c}\text { homozygous in } H S D 3 B 7 \\
\text { c.823 del GACGATT }\end{array}$ & 3ß-HSD deficiency & 8 \\
\hline 3 & $6 \mathrm{mo}$ & M & $33 / 384$ & $3.1 / 0.7$ & $\begin{array}{c}\text { compound heterozygous in } \\
H S D 3 B 7 \\
\text { c. } 412 \mathrm{G}>\mathrm{T} \\
\text { c. } 464 \mathrm{C}>\mathrm{T} \\
\text { c.974-974 ins CCTGC }\end{array}$ & 3ß-HSD deficiency & 13 \\
\hline 4 & $8 \mathrm{mo}$ & $\mathrm{F}$ & 76 / 679 & $8.3 / 2.7$ & $\begin{array}{c}\text { compound heterozygous in } \\
\text { SRD } 5 B 1 \\
\text { c. } 378+2 \mathrm{t}>\mathrm{c} \\
\text { c. } 668 \mathrm{G}>\mathrm{A}\end{array}$ & $\begin{array}{l}\text { 5ß-Reductase } \\
\text { deficiency }\end{array}$ & 9 \\
\hline 5 & $6 \mathrm{mo}$ & M & 46 / 441 & 3.4 / not done & $\begin{array}{c}\text { compound heterozygous in } \\
\text { SRD5B1 } \\
\text { c. } 797 \mathrm{G}>\mathrm{A} \\
\text { c. } 580-14 \mathrm{a}>\mathrm{g}\end{array}$ & $\begin{array}{l}\text { 5ß-Reductase } \\
\text { deficiency }\end{array}$ & 10 \\
\hline 6 & $9 \mathrm{mo}$ & $\mathrm{F}$ & $61 / 229$ & $3.6 / 5.2$ & $\begin{array}{c}\text { compound heterozygous in } \\
\text { SRD } 51 \\
\text { c. } 737 \mathrm{G}>\mathrm{A} \\
\text { c. } 850 \mathrm{C}>\mathrm{T}\end{array}$ & $\begin{array}{l}\text { 5ß-Reductase } \\
\text { deficiency }\end{array}$ & 10 \\
\hline 7 & $6 \mathrm{mo}$ & $\mathrm{F}$ & $36 / 345$ & $7.7 / 6.5$ & $\begin{array}{c}\text { compound heterozygous in } \\
C Y P 7 B 1 \\
\text { c. } 582 \mathrm{C}>\mathrm{T} \\
\text { c. } 417 \mathrm{C}>\mathrm{T}\end{array}$ & $\begin{array}{l}\text { Oxysterol } 7 \alpha \\
\text { deficiency }\end{array}$ & 11 \\
\hline Median & $8 \mathrm{mo}$ & & $36 / 384$ & $4.5 / 3.4$ & & & \\
\hline (Range) & $\begin{array}{l}\text { (6mo to } \\
22 \mathrm{yr})\end{array}$ & & $\begin{array}{c}\text { (23 to } 76 / 45 \text { to } \\
679)\end{array}$ & $\begin{array}{c}\text { (3.1 to } 8.3 / 0.7 \text { to } \\
6.5)\end{array}$ & & & \\
\hline
\end{tabular}

BASD, bile acid synthesis disorders; GGT, $\gamma$-glutamyltransferase; ALT, alanine aminotransferase; D Bil, direct bilirubin; TBA, serum total bile acids

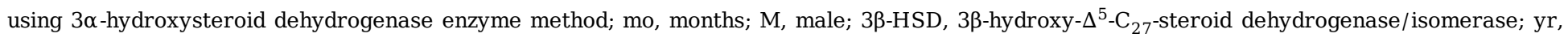
years; F, female; $5 \beta$-reductase, $\Delta^{4}$-3-oxosteroid $5 \beta$-reductase; oxysterol $7 \alpha$, oxysterol $7 \alpha$-hydroxylase; Patients 4 and 5 were re-analyzed by targeted next-generation sequencing in this study while other patients were analyzed by Sanger sequencing as previously reported in ref. nos.

8,10,11, and 13 .

\section{Supplementary Files}

This is a list of supplementary files associated with this preprint. Click to download.

- BASDjapanSuppFigOJRD.jpg 